\title{
ELECTRICAL INSTALLATIONS ANALYSIS AND RISK-ATTENUATION IN LOW-INCOME HABITATIONS INSPIRED BY PROJECT-BASED LEARNING
}

\author{
M. MENDONÇA \\ Universidade Federal Tecnológica do Paraná \\ mendonca@utfpr.edu.br
}

Received 10/10/2018 - Accepted 19/11/2018

DOI: $10.15628 /$ holos.2018.7835

\section{ABSTRACT}

The concept of social responsibility in engineering is the obligation that its professionals have to evaluate the impact of their work on public welfare. Although being a content presented in classrooms, the students in our university do not have contact with real-world situations of risk of electrical shock and fires caused by improperly electrical installations. To attenuate this deficit we created the undergraduate extension project "Analysis and Correction of Electrical Installations in Low-Income Habitations in the city of Cornélio Procópio" in the Federal University of Technology-Paraná. In this work, we focus on electrical installations safety conditions inspection and corrective actions in low-income habitations in Cornélio Procópio, Brazil. Our inspiration
\end{abstract}

is the Project-Based Learning (PBL), in which we insert students in real-world environments to point out and analyze electrical installations problems. In our project, a group of students and a supervising professor inspect the situations of risk according to a decision tree and make repairs in the electrical installations in the visited habitations. We created a socioeconomic form answered by each family visited and photos in order to obtain data for archiving. At the end, the students answered a qualitative form that verified the impact of the project in their learning and practical skills, and their awareness of social responsibility as engineers. We verified that the repairs improved the life quality of the residents. Finally, we address quantitative future work.

KEYWORDS: Electrical Engineering, Project-based Learning, Social Responsibility.

\section{ANÁLISE E ATENUAÇÃO DE RISCOS DE INSTALAÇÕES ELÉTRICA EM MORADIAS DE BAIXA-RENDA COM INSPIRAÇÃO EM APRENDIZAGEM BASEADA EM PROJETOS}

\section{RESUMO}

O conceito de responsabilidade social em engenharia é a obrigação que seus profissionais tem de avaliar o impacto de seu trabalho no bem-estar público. Apesar de ser um conteúdo apresentado em salas de aula, os alunos da Universidade Tecnológica Federal do Paraná, Cornélio Procópio, não possuem contato com situações reais de riscos de choque elétrico e de incêndios causados por instalações elétricas inadequadas. Para atenuar esse déficit criou-se o projeto de extensão da graduação "Análise e Correção de Instalações Elétricas em Habitações de Baixa Renda na cidade de Cornélio Procópio" na Universidade Federal de Tecnologia do Paraná. Nesse trabalho, foca-se nas inspeções das condições de segurança de instalações elétricas e ações corretivas em habitações de baixa renda em Cornélio Procópio, Brasil. A inspiração é a Aprendizagem Baseada em Projetos ( $\mathrm{PBL})$, na qual insere-se estudantes em ambientes do mundo real para apontar e analisar problemas de instalações elétricas. No projeto proposto, um grupo de estudantes e um professor supervisor inspecionam as situações de risco de acordo com uma árvore de decisão e fazem reparos nas instalações elétricas nas habitações visitadas. Um formulário socioeconômico foi criado, e respondido por cada família visitada e fotos para obter dados para arquivamento. No final, os alunos responderam a uma ficha qualitativa que verificou o impacto do projeto em suas habilidades de aprendizagem e prática, e sua consciência de responsabilidade social como engenheiros. Verificou-se que os reparos melhoraram a qualidade de vida dos moradores. Finalmente, abordouse trabalhos quantitativos futuros.

PALAVRAS-CHAVE: Engenharia Elétrica, Aprendizagem Baseada em Projetos, Responsabilidade Social. 


\section{INTRODUCTION}

We can define responsibility as the value orientation for making our actions. In the professional context, it is the duty to improve the lives of disadvantaged populations (Canney \& Bielefeldt, 2015), e.g. by the improperly electrical installations risk-attenuation made in this work.

Therefore, the sense of safety is important so that people in conditions of social vulnerability are no longer exposed to precarious access to electricity. Thus, a safety environment comply with the electrical circuit home regulations in order to avoid electrical shocks and fires. Thereby, this work aims to attenuate the risks in electrical installations with minimal changes to secure or even improve the physical integrity of the people and their belongings.

During the period from 2007 to 2011, the National Fire Protection Association (NFPA) estimates that fire departments in the United States of America responded to an average of 3.34 fires in commercial offices a year. In addition, electrical distribution and lighting equipment were the second largest cause of fire (12\%), causing $15 \%$ of direct damage to the analyzed properties (Campbell, 2013).

Several factors contribute to the use of precarious electrical installations, such as scarcity of resources, lack of knowledge of technical norms, and the construction of improvised houses on expropriated or invaded land, without basic sanitation etc. The need for electrical energy for lighting and daily tasks induces the practice of life-threatening installations.

The fire in the Joelma building in São Paulo, Brazil, an important event occurred in 1974, was caused by an electric short circuit due to the poor installation of an air conditioner, an example of non-standardized and supervised installations risks (Sharry, 1974). Recently, the Wilton Paes de Almeida building, also in São Paulo city, target of invasions since the 2000s, suffered a fire due to poor electrical installation that caused the building collapse, with deaths and losses for the Union (Darlington, 2018). The favelas are another example of a place with precarious electrical installations, sometimes obtained illegally and in non-compliance with regulated standards.

In this paper, the main objective is to present our work in the extension project "Analysis and Correction of Electrical Installations in Low-Income Habitations in the city of Cornélio Procópio". A group of students from the Federal University of Technology - Paraná (UTFPR-CP), conducted the extension project under the guidance of a supervising professor. Due to the difficulty to quantify the risks of electrical shocks and fires, we first worked only through a qualitative methodology.

Our motivation consists in improve and incentive the teaching of practical skills in the UTFPR-CP. The university's mission is the excellence in technological education through teaching, research, and extension projects. Although, extension projects aiming to engineering social responsibility are not valued as the projects that focus prizes and competitions.

The extension project approached low-income families in the city of Cornélio Procópio, in the north of Paraná state in Brazil. The objective was to identify possible risks in electrical installations in the habitations. In cases considered more severe, we tried to attenuate 
voluntarily the precariousness according to the safety standards set by the Brazilian National Electric Energy Agency (ANEEL) and the Brazilian National Standards Organization (ABNT).

The project aimed to make students and residents aware of the need to comply with safety standards for electrical installations in habitations, reducing the risk of accidents due to electric shocks, and prevent fires. Thus, students can learn in practice the concepts studied at the university, combining theoretical and practical aspects of low voltage electrical installations, relevant to their personal and professional growth. After observing the conditions of the habitations approached by the project, we verified the need to help the families involved through food donation, not in the scope of this work.

Finally, the application of the Project-Based Learning (PBL) technique, inspired by innovative learning techniques such as in (Copot, lonescu, \& Keyser, 2016; Fonseca \& Gómez, 2017; Martinez-Rodrigo, Lucas, Pablo, \& Rey-boue, 2017; Weltman, 2007), inserting the students in a real environment. Specifically, to present in a real environment the need to use technical and safety standards, the PBL is used to suggest and apply practical solutions to attenuate the problems found. Moreover, the students could combine the electrical installations (repairs), safety engineering, and strategic planning (decision-making) undergraduate disciplines.

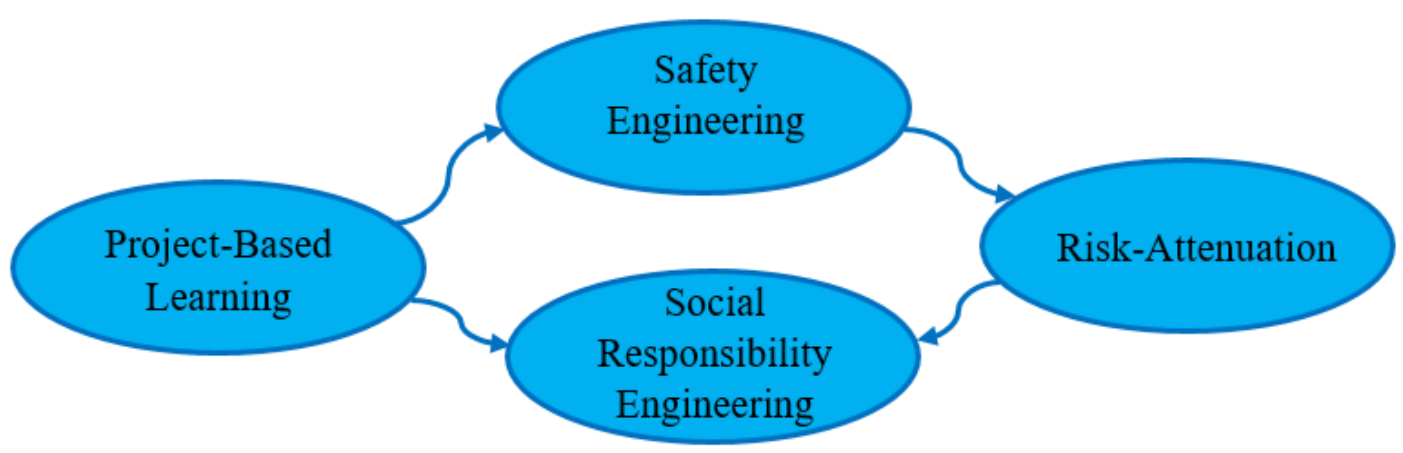

Figure 1: Conceptual map of our work.

We present, in Figure 1, a simple graphical conceptualization of our work. In it, the PBL concept generates a flow that benefits students and residents: the first ones can learn in practical the electrical installations standards, and the last ones get an improvement in their life quality. Thereby, the students become aware of their actions as engineers, helping them in their development as future engineers.

We describe the structure of the work below. In Section 2, we present the work's fundamentals, its stages of development and the methodology used. Section 3 shows the development of the project, also presenting the data of the families living in the habitations. Section 4 presents some of the cases analyzed, the repairs made and considerations about the actions. Section 5 concludes the work and addresses future work.

\section{MATERIALS AND METHODS}

One of the concepts approached in this work is Active Learning (AL), introduced by R. W. Revans (Weltman, 2007). In short, AL is a learning method in which students are actively involved 
in the learning process. Consequently, the knowledge acquired depends on student's involvement (Bonwell \& Eison, 1991).

The $A L$ is a technical term for a set of pedagogical practices that address the issue of student learning from a different perspective of classic learning techniques, such as discursive classes, where the teacher is expected to teach and the student to learn. Hence, it is understood that the student should not be merely a "receiver" of information, but must actively engage in acquiring knowledge, focusing on his goals and proactively pursuing it (Bonwell \& Eison, 1991).

In this work, the mainly inspiration is the PBL. In it, the proposal for pedagogical activity is directed by the presentation of problems to the students, who should actively seek methods for their resolution. Its use is particularly interesting in disciplines involving sciences and engineering used mainly in the area of health some decades ago.

However, in recent years, engineering courses in Brazil have already been successfully adopted the PBL. In this context, the limitations of the traditional teaching proposal, in addition to the growing innovations that have encouraged the scientific community to research alternatives for new teaching and learning processes, are able to train future engineers with a holistic view (Felder \& Silverman, 1988).

Several works show applications of active methodologies such as AL and PBL. In (Oleagordia, Barrón, San Martín, \& Asensio, 2014) the authors focuses on describing the aspects of a joint of PBL and cooperative learning in the area of higher education in Europe. The action consists of the project, testing and implementation of a solar energy battery charging system.

The use of active methodologies is presented in (Fonseca \& Gómez, 2017) for teaching software engineering in computer engineering in Chile. In this case, the authors aimed to improve students' grades with the integration of the learned contents with the development of projects within an industrial context.

In Brazil, the use of active methodologies can be observed in (Gazzoni, Miyoshi, \& de Lima, 2017), with the teaching of Calculus in engineering courses. The paper's goal was to insert technical content in the students' routine, assisting in the association of concepts with the subjects, which allows the students to make their own contributions and reach higher levels of understanding.

We can also mention (Prasad, Wicklow, \& Traynor, 2018). This interdisciplinary project uses a group of students and faculty from the Computer Science and the Biology departments to solve a social community problem. In (Fonseca \& Gómez, 2017; Gazzoni et al., 2017; Oleagordia et al., 2014; Prasad et al., 2018) the objectives were accomplished, with the students achieving better grades and presenting an evolution of their critical awareness.

In summary, the PBL-based techniques allows a shift from a teacher-centered environment to a problem-centered or real-life environment, which has inspired the abovementioned extension project. This technique is employed through existing stimuli in the proposed problem, and the student works autonomously, building his own knowledge and generating a solid knowledge.

Through the teaching of the concepts of $A L$ and $\mathrm{PBL}$, a group of students performed several technical visits in habitations on the periphery of Cornélio Procópio city (Paraná, Brazil), 
investigating the situation of the habitations' electric circuits, according to the appropriate authorizations of the residents.

Thus, the students documented the habitations by photos and taking notes of the most visible problems, making the appropriate electrical measurements. Thereby, we selected to benefit the most serious cases found. For the project's next stage, we collected data from the residents through a form and we made the analysis of the main risk points of the habitations.

The heads of the families answered the form, consisting of questions about the family members' education level, total income, if there were already domestic accidents with electricity and the authorization to carry out the extension project in the habitations. Thus, we performed a brief technical evaluation of the installations to designate possible new illumination spots, power plugs, switches etc.

A priori, we conducted the actions in a corrective way, aiming to attenuate the personal safety of the residents, consequently reducing the risk of electric shocks and fires. Thus, the guiding teacher was responsible for analyzing proposals for improvements and corrections, concluding what we would made.

After collecting the essential data and the making of meetings in our university to outline the action plan, we sought resources for the purchase of materials necessary to the expected repairs. Fundraising took place through training activities, actions of the private initiative, and incentives from the UTFPR-CP, and a lecture held by the extension project group and the project coordinator.

The complete visitation and repair ontology described above consists of four steps, as seen in Table 1. The steps summarize the main concepts approached. Hence, the extension project needed evaluation and validation methods. Thus, we assumed that a form was capable to provide the necessary data for the interpretation of the project's impact in the students.

Table 1: Ontology of the Extension Project

\begin{tabular}{c|l}
\hline Step & \multicolumn{1}{|c}{ Action } \\
\hline 1 & Habitation visit in order to identify the electrical problems \\
2 & Verification of the possible solutions according to the ABNT and ANEEL standards \\
3 & Define the actions to totally or partially repair the problems found \\
4 & Execution of the actions in pairs, exploring the concepts of AL and PBL \\
\hline
\end{tabular}

The data analysis monitored the dynamics and the construction of qualitative and quantitative indicators that aid in the decision-making and the strategic planning of future steps in this work. Thus, we used a method inspired by the topics usually approached in technical visits, considering the first stage of the project as an analysis done by the professor and the students of the problems found through the feasibility of the solutions given by the technical standards.

\section{DEVELOPMENT}

We formally made the corrections according to a decision tree proposed by the supervising professor, as shown in Figure 2. In short, a decision tree consists of nodes (attributes) 
and leaves (decisions or actions) linked through the possible outcomes of the branches (Wang, Li, Yu, \& Liu, 2018).

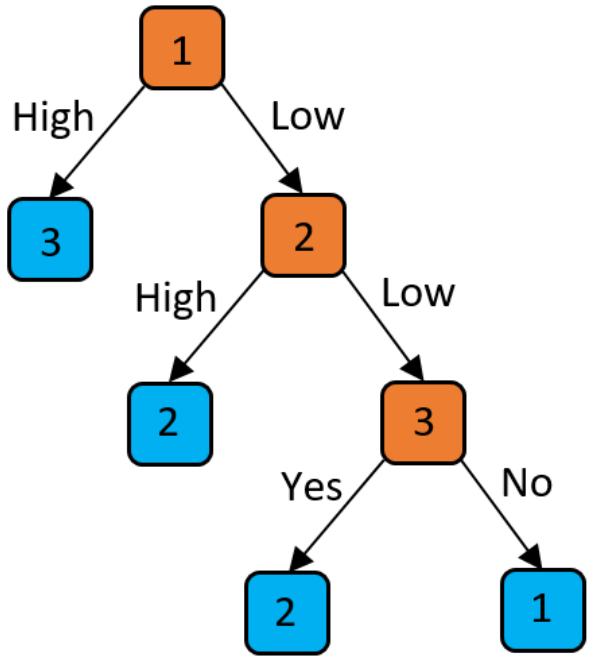

Figure 2: Decision tree.

In this work, we approached the attributes about the precariousness in the wirings and lighting equipment risk of fire (1) and electrical shock (2), composed by the quality of the insulation and quantity of wiring patches. The last attribute is the lack of adequate lighting (3). It is noteworthy that the attribute 1 automatically corresponds to the complete substitution of the electrical installations. Table 2 shows an example dataset to guide the group of students' decision-making process.

Table 2: Example dataset

\begin{tabular}{c|c|c|c|c}
\hline \multirow{2}{*}{ Id } & \multicolumn{3}{|c|}{ Attributes } & \multirow{2}{*}{ Action } \\
\cline { 2 - 4 } & $\mathbf{1}$ & $\mathbf{2}$ & $\mathbf{3}$ & \\
\hline 1 & low & low & yes & 2 \\
2 & low & low & no & 1 \\
3 & low & high & yes & 2 \\
4 & high & low & yes & 3 \\
5 & high & high & no & 3 \\
\hline
\end{tabular}

We divided the risks of fire and electrical shock attributes in "low" and "high", and the lack of adequate lighting is composed of "yes" or "no". Thus, the leaves of the decision tree are the correction actions of the group.

The first action is "counseling", applied in cases where the conditions found do not present alarming risks to the residents. We used the second one, "small repairs", in cases where there is an imminent risk of electric shock to the residents. When necessary, can include the installation of lamps and light switches. The third one is the "total substitution", chosen in the most severe cases, when the electrical installations can immediately harm several human lives and cause fires. 


\subsection{Social and technical aspects}

We periodically visited he habitations during the total duration of the extension project (approximately ten months). We divided the visits in two stages, firstly, with the investigation of the needs of the habitation through the completion of the socioeconomic form, and secondly, we made the repairs. As mentioned previously, we sought donations of construction materials from shopkeepers and other residents of the city in order to try to meet some of the needs of the residents approached.

The results from the socioeconomic form indicated that the number of residents per habitation (5.25) exceeds the average number of persons per household, 3.3, according to the Brazilian Institute of Geography and Statistics (IBGE) in the most recent statistic (2011). In 75\% of the visited habitations, the sum of the income of all residents is less than or equal to a minimum wage of R\$ 954.00 (Brazilian currency, Reais). This amount is equivalent to US\$260.00, demonstrating the difficulty situation of the families, since the country is experiencing an economic crisis.

According to the data collected from the observation and documentation of the habitations, we verified that none was within the ABNT standards, in particular the NBR-5410. The habitations did not have properly electrical plant or some protection device against electrical discharges, due to the lack of residents' financial and technical conditions. Guidelines for installations, calculation of wire diameters, circuit breakers, demand, grounding etc. were made according to the ABNT and ANEEL standards.

From the socioeconomic form, all families approached reported accidents with electricity in their habitations, in most cases without medical care. Major accidents occurred with bare wires, power plugs, switches, and showers without proper wall attachment and grounding. We show two of the situations found in Figure 3. Note that the wires should not be tied in the water pipe due to the power leakage and electrical shock danger.

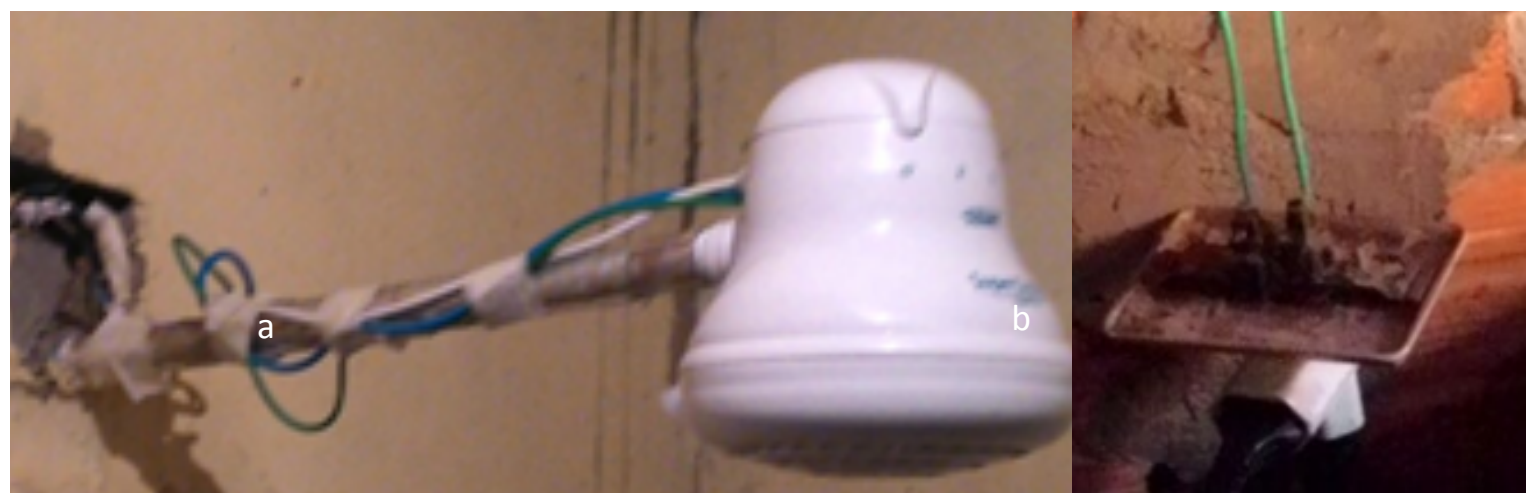

Figure 3: Precarious installations of (a) electric shower and (b) power plug.

The Figure 3 (a) illustrates a recurrent case found by the members. Occasionally, due to lack of resources, the electrical shower wires are tied with tape, giving a false sense of security to the residents. In this particular case, there was also a lack of grounding, increasing the risk of accidents due to electric shocks. Thus, in Figure 3 (b) we can observe the wiring terminals exposed causing an elevated risk of electrical shocks, especially for children. 


\subsection{Form presented for student evaluation}

After the extension project end, we elaborated an online form to be answered by the students in order to verify the impact of the work on their learning and practical skills. We present below the form's objectives.

First: Lead academics to establish relationships between theoretical and practical content. Second: Exercise analytical, observation and critical skills. Third: To interact creatively in the face of different technical and productive contexts. Fourth: Align systematized knowledge with professional action. Fifth: Seek the development of systemic vision. Sixth: Interact with the different professionals in the area, aiming to broaden and deepen professional knowledge. Seventh: Stimulate the student to scientific and field research.

The form contains seven discursive questions, detailed below, about the experiences of the students in the extension project. You can found the form and its questions at https://goo.gl/forms/FyTSBVk7de7unbdI2. In the next section, we present the students' considerations.

\section{RESULTS AND DISCUSSION}

The structural conditions of the habitations analyzed were precarious, with fragile walls that made it difficult to repair the electrical components. In addition, we found situations of great risk of electric shocks and fires. This section aims to show the repairs and discuss the risk to the residents.

\subsection{Cases found in the habitations}

As discussed in the previous sections, in this work we selected four habitations by the extension project. The aim of this section is to show and discuss the cases found, presenting the corrections and the security solutions performed by the members.

In a case, we found an improvised light switch fixed to a wall, with a considerable gap that allows electric shock risks for adults and children. There was also the presence of a lighter attached to the first switch, increasing the chances of accidents.

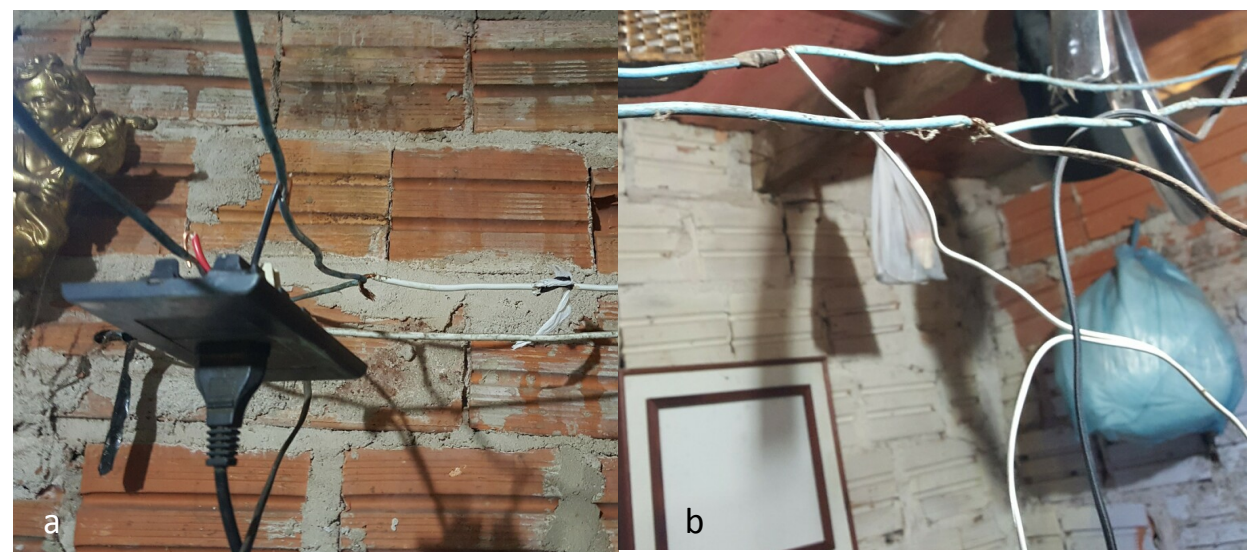

Figure 4: Exposed wiring, high number of patches. 
Moreover, Figure 4 (a) and (b) presents other insecurities found in the habitations. In these cases, the group of students was dedicated to improving risk points by properly isolating the bare wires, securing them whenever possible to sockets, switches and illumination points. We relocated or removed all loose and/or changed the wiring in order to minimize the risk of electric shock or short circuits.

As seen in Figure 4 (a) and (b), a recurrent case was the presence of exposed wiring in places with large circulation of people, and at heights within reach of children. The cases demonstrate the precariousness found and the risk to the lives residing in the habitations.

We also considered the residents' comfort as a background objective for the corrections and improvements made. One of the habitations had a lamp installed incorrectly with its bare connections in a kitchen corner. In this case, the respective light switch was in the living room, and to power the lamp it was always necessary to the resident to move to the other room.

The solution was to change the position of the lamp to the kitchen center, and swap the wiring with a new switch installed in the same room, next to the door to make it easier to switch on the lights when the residents enter the kitchen.

For an improvement of visual comfort, in some cases, we implemented new lighting points, and relocated switches to other locations for better access for the elderly and children. We performed an awareness work, in which the members of the families were explained the risks that the electrical network can cause.

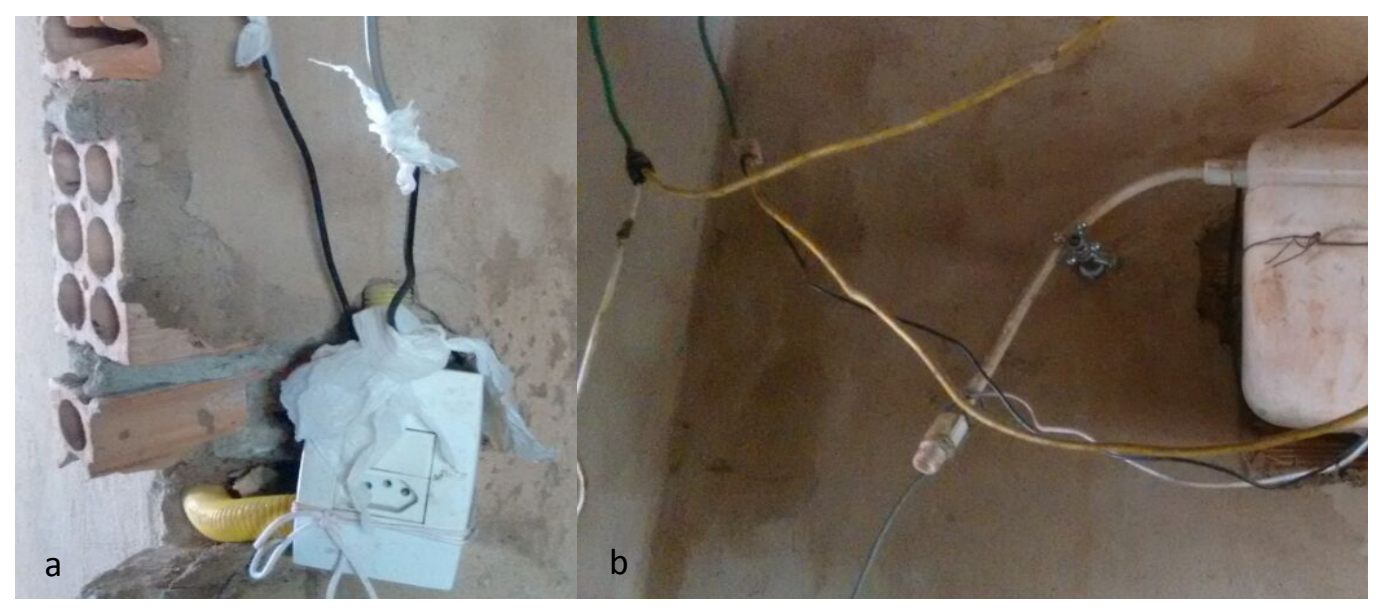

Figure 5: Exposed wiring, high number of power plugs and patches.

As seen in Figure 5 (a) and (b), we installed a new light switch/socket in the bathroom. However, the walls were in poor condition, making it impossible to repair correctly. We replaced the wiring that connected the switch to the lamp, whereas we repaired the melted wiring of the shower in order to remove any damaged parts.

The Figure $6(\mathrm{a})$ and $(\mathrm{b})$ shows the result of the corrections made in the situation found in Figure 5. In this case, we can observe better isolation and fixation of the components, with the socket being no longer patched by wires bounded to a plastic bag. 


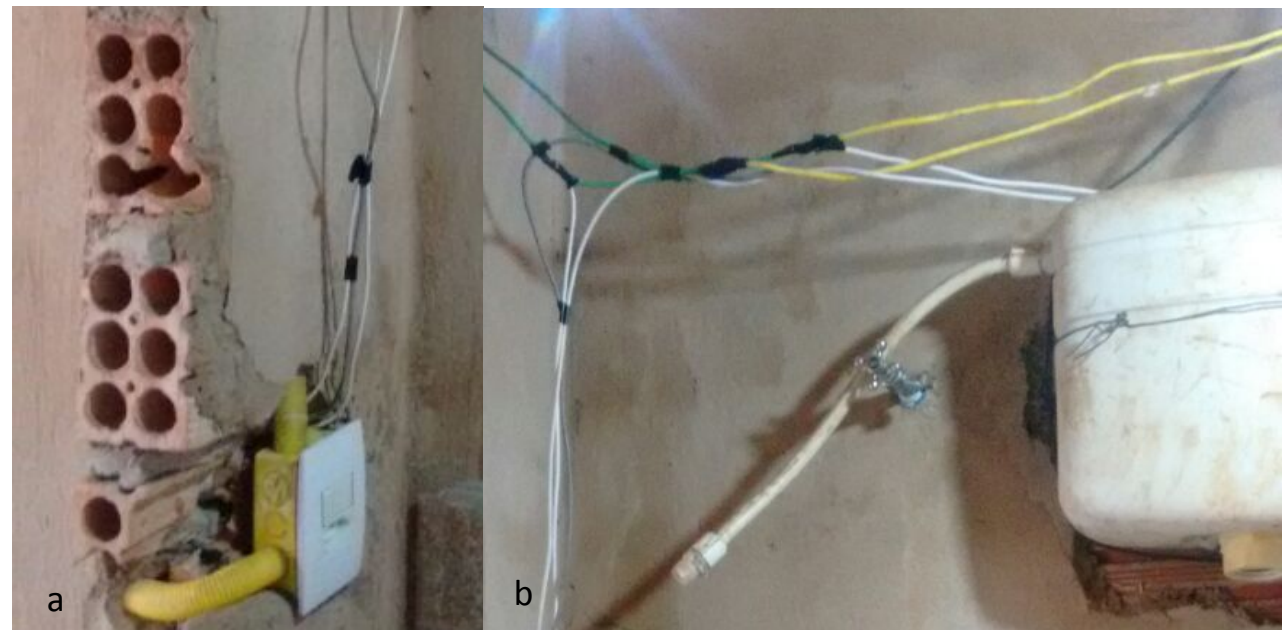

Figure 6: Corrections made in the bathroom (Figure 5).

We show in Figure 7 a power plug in precarious conditions. In it, there is a high risk of a resident stumbling on the wires, taking into account that in the analyzed room there was no light point. Moreover, the connected devices have improperly wiring patches, evidencing the risk of electrical shocks.

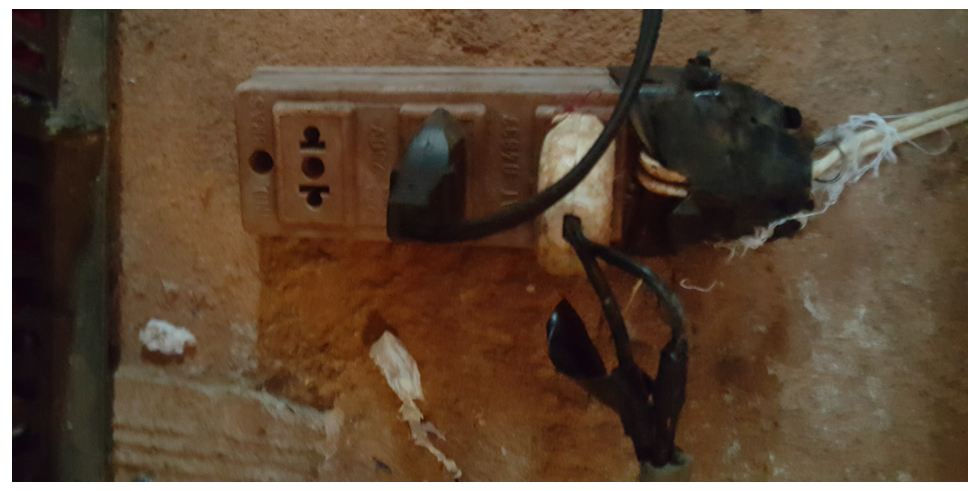

Figure 7: Exposed wires and high amount of devices in the same power plug.

We observed the lack of circuit breakers and separate circuits in the habitations. We witnessed circuit breakers only in two habitations when the standards state one per circuit. Besides, all habitations visited had improperly wiring repairs and none had grounding. These facts suggests a need to reinforce the learnings of safety standards and electrical installations concepts, commonly discussed theoretically and in laboratories.

The low luminosity brought extra safety care during the visits, done mainly at dusk according to the students' availability. This fact was aggravated by the lack of circuit breakers, since induced the total shutdown to perform the corrections and improvements.

With a higher budget, we could made better-quality corrections, with the use of apparent conduits instead of exposed wires, and better illumination and socket arrangement in order to meet families' needs. The structure of the habitations also characterized an obstacle for the work's accomplishment. Fragile walls, poor quality finishes and lack of ceilings prevented fixation 
of elements in some cases. One possible solution for this problem is to ask for civil construction companies' aid, in the form of labor or even as a sponsorship.

\subsection{Form considerations}

Four students participating in the extension project answered the online form. In short, we observed a positive feedback from the answers. The students felt an increase of their capability of problem-solving, social interaction and critical consciousness.

The comments for the project's evolution were an important aspect considered. In this question, the students suggested a partnership with the city leaders in order to improve the quality of the habitations as a whole, aiming to repair its structures in the dangerous cases.

Another point is to increase the number of participants of the extension project and promote advances in the documentation process used in this phase of the project, mainly by photos.

One of the students requested for more instructions to the residents in the moment of the repairs in order to increase the general acceptance and caution in the next installations. We also cited the problem of the University's financial support, which could help in the repairs' quality and quantity.

\section{CONCLUSIONS}

The extension project achieved the desired objectives, helping the families approached with improvements in the electrical installations. Hence, giving students a different point of view of the reality they are familiar to. This fact helps to build the social awareness of the individual, and assists in the practice of installing the electrical components and in the handling of the tools used.

In addition, the project demonstrated to participants the importance of working safely and the benefits of applying the standards to attenuate risks from electrical installations. Another factor observed was that the visits to the habitations developed a bond with the residents and the students, creating an overview of their responsibility to perform a safe service as engineering professionals in the latter.

Despite the evident contribution of this extension project, the biggest difficulty was the fundraising to provide electrical installations in accordance to the safety standards. The lack of sponsorship from local merchants was the major problem encountered by the idealizers, due possibly to the early stages of this initiative.

Finally, we observed that the families were aware of how to avoid the accidents caused by the electrical energy use. We spare no thanks to the involved. Future works addresses the development of a database for better information management and the analysis in other communities and the promotion of lectures to raise awareness of the problems observed. Moreover, we will use a fuzzy cognitive map tool in a try to diagnose quantitatively the risks and/or the social responsibility impact in the engineering students, and improve the UTFPR-CP engagement with the community. 


\section{REFERENCES}

Bonwell, C. C., \& Eison, J. A. (1991). Active Learning: Creating Excitement in the Classroom. ASHEERIC Higher Education Report (1st ed.). Washington, USA: School of Education and Human Development, The George Washington University. https://doi.org/ED340272

Campbell, R. (2013). U.S. Structure Fires in Office Properties. National Fire Protection Association Fire Analysis and Research Division. Quincy, MA, USA.

Canney, N., \& Bielefeldt, A. (2015). A Framework for the Development of Social Responsibility in Engineers. International Journal of Engineering Education, 31(1(B)), 414-424.

Copot, C., Ionescu, C., \& Keyser, R. De. (2016). Interdisciplinary project-based learning at master level: control of robotic mechatronic systems. In IFAC-PapersOnLine (Vol. 49, pp. 314-319). Elsevier. https://doi.org/10.1016/J.IFACOL.2016.07.196

Darlington, S. (2018). Fire in São Paulo, Brazil, Brings Down a High-Rise Building. Retrieved July 27, 2018, from https://www.nytimes.com/2018/05/01/world/americas/sao-paulo-brazilfire-collapse.html

Felder, R. M., \& Silverman, L. K. (1988). Learning and teaching styles in engineering education. Engineering Education, 78(7), 674-681. https://doi.org/10.1109/FIE.2008.4720326

Fonseca, V. M. F., \& Gómez, J. (2017). Applying Active Methodologies for Teaching Software Engineering in Computer Engineering. Revista Iberoamericana de Tecnologias Del Aprendizaje, 12(3), 147-155. https://doi.org/10.1109/RITA.2017.2738178

Gazzoni, W. C., Miyoshi, J., \& de Lima, V. D. P. (2017). Active Methodologies for Calculus in Engineering Courses (December 2016). Revista Iberoamericana de Tecnologias Del Aprendizaje, 12(4), 193-198. https://doi.org/10.1109/RITA.2017.2776441

Martinez-Rodrigo, F., Lucas, L. C. H., Pablo, S. De, \& Rey-boue, A. B. (2017). Using PBL to Improve Educational Outcomes and Student Satisfaction in the Teaching of DC/DC and DC/AC Converters. IEEE Transactions on Education, 60(3), 1-9. https://doi.org/10.1109/TE.2016.2643623

Oleagordia, I. J., Barrón, M., San Martín, J. I., \& Asensio, F. J. (2014). Active methodology applied in engineering by PBL. I-Approach. Proceedings of XI Tecnologias Aplicadas a La Ensenanza de La Electronica (Technologies Applied to Electronics Teaching), TAEE 2014. https://doi.org/10.1109/TAEE.2014.6900181

Prasad, R., Wicklow, B., \& Traynor, C. (2018). Practical Problem-Based Learning: An Interdisciplinary Approach. In 2018 IEEE Integrated STEM Education Conference (ISEC) (pp. 258-261). Princeton, NJ, USA: IEEE. https://doi.org/10.1109/ISECon.2018.8340496

Sharry, J. A. (1974). South America Burning. Fire Journal, 68(4), 23-33.

Wang, L., Li, Q., Yu, Y., \& Liu, J. (2018). Region compatibility based stability assessment for decision trees. Expert Systems with Applications, 105, 112-128. https://doi.org/10.1016/J.ESWA.2018.03.036

Weltman, D. (2007). A Comparison of Traditional and Active Learning Methods: An Empirical Investigation Utilizing a Linear Mixed Model. PhD Thesis. The University of Texas at Arlington. https://doi.org/10.1017/СBO9781107415324.004 